\title{
IUETAL
}

\section{Education and Proto Language Maintenance at Orang Rimba in Jambi Province}

\author{
Diana Rozelin \\ UIN Sulthan Thaha Saifuddin Jambi \\ e-mail:dianarozelin@uinjambi.ac.id \\ Umar Fauzan \\ IAIN Samarinda \\ e-mail:umar.fauzan@iain-samarinda.ac.id
}

\begin{abstract}
:
This research discussed education and dialectology, examining the relation of Orang Rimba $(O R)$ isolect in three places at Jambi Province. Different levels of education in each group of $O R$ also influence language maintenance at proto-language. Language shift will occur when $O R$ communicate with the villagers. The number of OR children who go to school does not guarantee a language shift. This study's benefit was to find out the proto vocabulary that still maintenance and shifted, to know the status of isolect from each group of OR to find out their kinship relations, and to know that education levels may not always affect vocabulary shifts. Dialectometry formula used from Guitar, Proto Austronesian (PAN) used theory from Wurm and Wilson, Proto Malayic (PM) used opinion from Adelaar. This study used qualitative and quantitative to answer different formulation of the problems. The result was: firstly, lexically and phonologically, the status of $O R$ isolect in Jambi, including three regencies consisted of two dialects, four subdialects, and four speeches. There were 5 proto vocals and 19 proto consonants phonemes of $O R$ in Jambi Province. The result of affixation identification at $P M$ ${ }^{*} t A r_{-} ;{ }^{*} m A N-; *(m b) A r-; *$-an; and *kA-an found innovation and no relic. Secondly, the reflex of PAN and PM at OR Malay dialect having the highest value in maintaining its proto-language (relics) occurred in DP 5,6 Muaro Jambi Regency. Thirdly, the number of children attending school in the villages of Nebang Parah and Nyogan was higher compared to other OR groups. The number of children attending school was in line with the high percentage of protolanguages used.
\end{abstract}

Keywords: dialectology, education, proto Austronesian, proto Malayic 


\section{Introduction}

Indonesian is a multiplot society, rich in culture, language, and religion that appear in the complex society. The human characteristic and thinking could be seen when they are speaking or the words that they chose. Humans' character can be analyzed from how they appreciate their own culture, not shame to use their mother language in daily communication. The human language ability is a unique concept consisting of symbols, words, phrases, clauses, and sentences. Humans mastered that ability through their infants, even though it was just crying, but its sign belongs to language faculty and native language ability. Chomsky said (2000: xvii), Indriani and Ningrum (2017) stated the ability of human language is involved genetically, authentic, or is called by the human language power.

Language describes human thinking, attitude, and event that they faced. The situation that is faced by human beings usually produced in different words. Nowadays, local languages include to danger language or shift language because of technology, education, or communication (Effendy 2011). Indirectly, the Indonesian language contributed to making local languages be shift language because it used daily communication in education. This situation makes local languages derelict. Besides that, like English, Arabic, Japanese, and Mandarin contribute to the local language shift. It happened because the young generation likes to use such languages in their community to show their new identity.

Jambi society claimed that the isolect of Suku Anak Dalam or Kubu or Orang Rimba (next $\mathrm{OR}$ ) is not the same as Jambi Malay dialect. Jambi society thinks that OR is not Malayan people or outsiders. That opinion is in line with Kubu Language Dictionary published by Kantor Bahasa Jambi in 2013. Kubu Language Dictionary showed isolect from OR is not the same with Jambi Malay language.

The insight of OR isolect is not the same with Jambi dialect of Malay build upon previous research Dongen (1913b:16) said:

The unique existing of the Kubu language in a Malay language group showed that they had their language. In Dongen's book, a hundred years ago, Kubu people had done communication with the outsider. They did communication through an intermediary, and it's called Jenang. Jenang helped them interpret when they wanted to sell something. It happened because Kubu's language was difficult to understand by villagers or Malay people who lived around the forest.

That statement showed that initially, the OR group's isolect at Duabelas hill was not easy to understand. Piecemeal OR language could be realized by the Malay community who lived around Duabelas hill. At that time, maybe the isolect of OR was included in the language, and nowadays, it had shifted to become isolect or sub-dialect. It happened because of communication, condition of the area, marriages between OR groups at Duabelas hill, or contact continuously with villagers. It will be discussed further.

OR dislikes if Jambi Malay called them with Orang Kubu or Suku Kubu. This label was very rude; the meaning of that words was identified as backwardness. In another case, significance from the word Kubu point of view Jambi government was a fortress; a person who withstand in the weald. Otherwise, the significance of the word of Kubu had different 
in Malay people opinion. The word Kubu, in the Jambi Malay language, means a stupid person.

Since the 19th century, the existence of this minority group had been known. Some researchers analyzed them under the controlled Dutch government at Palembang Regency. One of the researchers, Dongen (1913a:5), noticed that Kubu people were categorized into Kubu liar (wild Kubu) and Kubu jinak (civilized Kubu). The people who lived in one area and could communicate with a villager or Malay People were called Kubu Jinak. The people who lived from one weald to another weald called by Kubu Liar do not want to talk with newcomers.

If we discuss about settlements category based on the writer's observation, so OR that lived at Tebo area was categorized: a) people who lived in the central of weald and settled; then b) people who settle at settlements close to Malay people's home (like lived at villagers' palm plantation). OR from Sarolangun regency was divisible into some groups: a) people who lived in weald then move from one region to another region; b) people who lived at the settlements or housing closed villagers' home. OR in Muaro Jambi regency was the people who lived in settlements from the government where their neighbor was villagers.

This study's focus consisted of six OR groups that lived in three regencies, and they were: Tebo, Sarolangun, and Muaro Jambi. Tebo regency had two groups; they were Tumenggung Njalo stayed in Kedondong Mudo village, Makekal Ulu. Depati Begantung in Tanah Garo village, Makekal Ilir. Sarolangun regency had two groups. Tumenggung Berendam stayed in the settlements or housing where that place still belonged to Singosari village, the last Tumenggung Betaring who stayed in Paku Aji village. Muaro Jambi regency had two groups Tumenggung Canggo stayed in Nebang Parah village, and Tumenggung Kubung stayed in Nyogan village. In this research, we focused on the status of isolect each area of OR in Jambi Province through lexically and phonologically; to describe PM in each area and to describe the development of $O R$ in Jambi and its relation to proto-language maintenance.

\section{Research Methodology}

This study used two types of research; they were: quantitative and qualitative research. It is used alternately. Qualitative research was used to describe the data that related to lexical and phonological. Quantitative research used to answer the result of lexical and phonological be tested using dialectometric formula.

Besides that, this research used a descriptive method with a reflex top-down reconstruction technique. It analyzed words shift and word maintenance from the old language, Proto Austronesia (next PAN), to the old middle language Proto Malayic (next PM). After that, this research would analyze the Malay isolect of $O R$ in Jambi province. The reference reconstruction was utilized to know the basics from word shift and word maintenance from PM written by Adelaar (1992) and PAN from Wurm and Wilson (1978). Quantitative research utilized a method of comparative where the words were compared between one group with another group. Meanwhile, this research utilized a dialectometric technique to specify each group's status (next DP). Meanwhile, this research used purposive sampling in choosing the informants. 


\subsection{Diachronic Linguistics}

Diachronic linguistics was the study that was divided into comparative historical linguistics and dialectology. Both subjects had the same object- words- as their primary data but different at reconstruction. First, comparative historical linguistics studied a language that compared two languages or more to look for the primary language. Comparative historical linguistics used lexicostatistic to look for the same words. Second, dialectology analyzed the words from different groups. And then, dialectology used dialectometric to look for the different words.

Mahsun (2010:33) said that dialectology study included in diachronic linguistic that learn about why the isolects are different and arise in a language. Something that had given a strong effect, for example, diverse variants emerge, it made by society or individual groups. The study about languages variety based on local difference language area called by dialectology (Nadra and Reniwati 2009:5; Rozelin and Azlan 2019; Fitria Dewi et al. 2017:61; Wiladati 2014:4). It means dialectology analyze languages to look for different words. So, related to this article, Jambi Province, as the observation focus, analyzed three regencies, and each regency was represented by two OR groups. This research was not only talked about synchronic but also diachronic aspect then used a dialectometric formula to determine the isolect status of each group currently.

Diachronic tried to find or reconstruct the words or syllables from the old language into the new language and then find out relic and Innovation at those words. Synchronic tried to find out the relation between all of OR groups in Jambi, Palembang, and Padang through different words by using dialectometric formula.

Another expert Trudgill and Chambers (1998:3) said that language is the unity of dialect that understands each other. This definition showed that dialect as the subdivision of language had criteria to differentiate one language from another. It means dialect consist of words that differ from one village to another village. In their book "dialectology," those experts stated that dialect was always related to crude language forms, the low-status language, work class, and low economic, social status. Dialect was also the form used to describe the language used in isolated areas that did not have a written language. The knowledge about dialectology was conducted for the first time by George Wenker in 1876 that analyzed Germany's dialect.

As we know, dialect describes a variety of a language, used in one area, or can be called by regional dialect. Another expert said that dialects used by people in the same social class, social dialect, or sociolect are sometimes different in some words, sentences, and pronunciation under the same language (Weber in Ling 2000: xxviii). So, isolect or dialect was the characteristic of one group of society has.

\subsection{Phonology}

The analysis of phonology was focused on the different syllable that included characteristics of phonetic and its categories (Robin 1975:17); in another case, McManis (1987:71) said that phonology was concerned with how these sounds are systematically organized in a language, how they are categorized by and interpreted in the minds of speakers, and how they are combined words form. Those sounds are organized systematically in one language. According to Lass (1991:3), phonology had two aspects they were: (a) learn or study the 
characteristic of sound and symbol that appear in words and (b) to analyze the relation of symbols or syllable in relation to other aspects of the entire description. It means every sound of the words had meaning.

Another opinion about phonology from some experts defined phonology as the knowledge that described the pattern and symbol of a word in a language. Each sound had its function (Crystal 1992: 160; Chaer 1994: 102; Cahyono 1995: 102; and Kridalaksana 2001:57). To analyze the function of words, especially the sound, we can learn it through phonetics. Phonetics learns the sound regardless of the function of sound within a language stated by Robins 1992: 149. So that, here, the authors describe Innovation as the reveal changed through protophoneme. Subroto (2011: 88) stated that a language, as time progresses, surely experiences the change in either its form or meaning or system or vocabulary. The apposite from Innovation was a relic. The relic was the phoneme sound that does not change from its protophoneme. This research analyzed Innovation and relic as the manifestation of sound change.

\subsection{Language Contact}

The primary function of language as the tool of communication to convey what existed in the speaker's or listener's mind, the expectation on something, and as self-identification. On another side, communication was the process of information exchange from the speaker to the listener using symbols or sign in formal, informal, spoken, written, or gestured language.

One of the requirements from the language shift was language contact. It is occurring in a society that had a different language and culture. The language contact itself had a relation with bilingualism and individual has. Bilingualism was the language ability an individual had, in addition to the mother tongue. All remarks about bilingualism apply to multilingualism, the practice of using alternately three or more languages (Weinreich, 1970: 1). Such individual bilingualism was related to its ability to use two or more languages.

As we know, language is a communication tool that gives information or reveals an individual's ability and showed his or her relationship with other people. Trudgill (1976: 1) also stated that language is not like a tool; it means language was not only talked about feeling or opinion but talked about the identity of human, the condition of one country, but also the safety of the world.

\subsection{Education}

Education nowadays has become a prominent thing in human life. Education is not only in the school but also outside the school itself. Both males and females need the education to make them more wise and brave in facing all the problems. Education in a small village looks like a choice. Sometimes, children should help their parents at palm plantation, but on another side, every human being or child has a right to go to school to receive a good education (Lee, Sharon 2013).

Siregar (2013: 11-27) further argues that The Minimum Age Conversion, about the notion of a child someone who is not yet 15 years old must protect and direct these children because in him the dignity and rights as human beings must be upheld. The object in this study were children who were at the elementary school level. This level of education is taken because at 
the elementary level, and there are more children than at the junior high school. The phenomenon that often occurs is that children are very easy to adopt new vocabulary from their school environment, home environment and leave old vocabulary. New vocabulary is brought into the family domain.

\section{Findings and Discussion}

The data were classified using a dialectometric formula based on Nothofer's Words Basic Vocabulary instrument consisting of 829 glosses and 100 sentences from all observation areas. The six observation areas (next DP) at Jambi were 5.574 data. The village's name was: DP 1 was Paku Aji, DP 2 was Singosari, DP 3 was Kedondong Mudo, DP 4 was Tanah Garo, DP 5 was Nyogan, and DP 6 was Nebang Parah. The finding showed 388 glosses of lexical variation, 257 glosses of phonological variation, and 184 glosses with no variation (zero).

The conclusion from lexical variation for each DP used dialectometric formula were: $23.45 \%$ for DP $5: 6,74.48 \%$ for DP $4: 5 ; 31.44 \%$ for DP $3: 4 ; 30.60 \%$ for DP $2: 4 i 31.70 \%$ for DP $2: 3$; $80.15 \%$ for DP 1:6; $79.38 \%$ for DP 1:5; $32.98 \%$ for DP $1: 4 ;$ and $33.24 \%$ for DP $1: 2$. The finding of lexical variation above was tabulated in the table 1.

Table 1. Lexical Variation Estimation

\begin{tabular}{lcccc}
\hline No & No. DP & $\%$ & Total & $\begin{array}{c}\text { Lexical } \\
\text { Variation }\end{array}$ \\
\hline 1 & $5: 6$ & 23.45 & 91 & W \\
2 & $4: 5$ & 74.48 & 289 & D \\
3 & $3: 4$ & 31.44 & 122 & S \\
4 & $2: 4$ & 30.67 & 119 & W \\
5 & $2: 3$ & 31.70 & 123 & S \\
6 & $1: 6$ & 80.15 & 311 & D \\
7 & $1: 5$ & 79.38 & 308 & D \\
8 & $1: 4$ & 32.98 & 128 & S \\
9 & $1: 2$ & 33.24 & 129 & S \\
\hline
\end{tabular}

Note:
$D$ = dialect variation
$\mathrm{S}=$ sub-dialect variation
DP = area observation
$\mathrm{W}=$ speech variation

Based on table 1, it was explained that DP 1 compared with DP 2; and DP 3 compared with DP 4. All the groups included sub-dialect variation because they appeared in the same group and the same regency. It means the kinship relation of those groups was close. Besides that, the result of isolect identity for area 1 compared with area $4 ;$ then, area 2 compared with area 3 included to dialect variation, but those from different regencies.

Meanwhile, DP 2 compared with DP 4 , and DP 5 with DP 6 included speech variation. The unique here was DP 5 and DP 6 from the same regency, Muaro Jambi, while DP 2 and DP 4 from different regencies. The lexical variation result showed that DP 5 with DP 6 included speech variation and DP 2 with DP 4 . It showed that they came from the same ancestor, and their kinship was very close to speech variation. 
DP $1: 4$ and DP $1: 2$ had the same percentage, $8.42 \%$, which belongs to sub-dialect. DP 1 and DP 2 came from the same area, while DP 1 and DP 4 came from a different area. The isolect status of sub-dialect variation indicated sufficiently close kinship relation. Begantung said that his brother had gotten married to a member of Bataring's group from Pematang Kabau village. This statement showed that the occurrence of marriage between the members of OR at Bukit Duabelas.

The isolect status of DP 5:6 was 6.15\%, and DP 2:4 was 7.74\%; they included the same group speech variation. Those groups' percentage indicated that they had close kinship relation and their vocabularies changed not too much although they lived near Malay society. This situation also happened with the groups DP 2 and DP 4 .

Besides that, DP 4 compared with DP 5 and then DP 1 compared with DP 5 and DP 6 ; the result was dialect variation. This result appears because of firstly, the distance between DP 1 and DP $5 ;$ DP 1 and DP 6 were far enough. Secondly, those groups were from different ancestors and different regencies. The area of 5 and DP 6 admitted that their ancestors from Palembang, while DP 1 and DP 4 from Padang. The result of phonological variation from those groups was tabulated in table 2 .

Table 2. Phonological Variation Estimation

\begin{tabular}{lcc|cc}
\hline No & No. DP & $\%$ & Total & P.Variation \\
\hline 1 & $5-6$ & 6.15 & 27 & W \\
2 & $4-5$ & 14.57 & 64 & D \\
3 & $3-4$ & 8.20 & 36 & S \\
4 & $2-4$ & 7.74 & 34 & W \\
5 & $2-3$ & 8.65 & 38 & S \\
6 & $1-6$ & 14.57 & 64 & D \\
7 & $1-5$ & 14.57 & 64 & D \\
8 & $1-4$ & 8.42 & 37 & S \\
9 & $1-2$ & 8.42 & 37 & S \\
\hline
\end{tabular}

Note:

$\mathrm{D}=$ dialect variation $\quad \mathrm{S}=$ sub-dialect variation

$\mathrm{DP}=$ area observation $\quad \mathrm{W}=$ speech variation

Based on the data above, the writers concluded isolect status for lexical and phonological variations were: sub-dialect variation, dialect variation, and speech variation. It also could be divided into sub-dialect and dialect variations; the smaller groups belong to the bigger one. It means DP 5 compared with DP 6 and DP 2 compared with DP 3 , and their status was speech variation and sub-dialect variation. The position of speech variation was lower than the sub-dialect. So that, DP 5 and DP 6 not include speech variation but include to the bigger above it, sub-dialect. So, the writers concluded that the status isolect OR in Jambi province just two kinds, they were:

Tabel 3. The Isolect Status of OR in Jambi Province

\begin{tabular}{lll}
\hline NO & DP & ISOLECT STATUS \\
\hline $\mathbf{1}$ & $1,4,5,6$ & Dialect Variation (BD) \\
$\mathbf{2}$ & $\mathbf{2 , 3}$ & Sub-Dialect Variation \\
\hline
\end{tabular}




\section{Map 1. Dialectrometrical Polygonal Map}

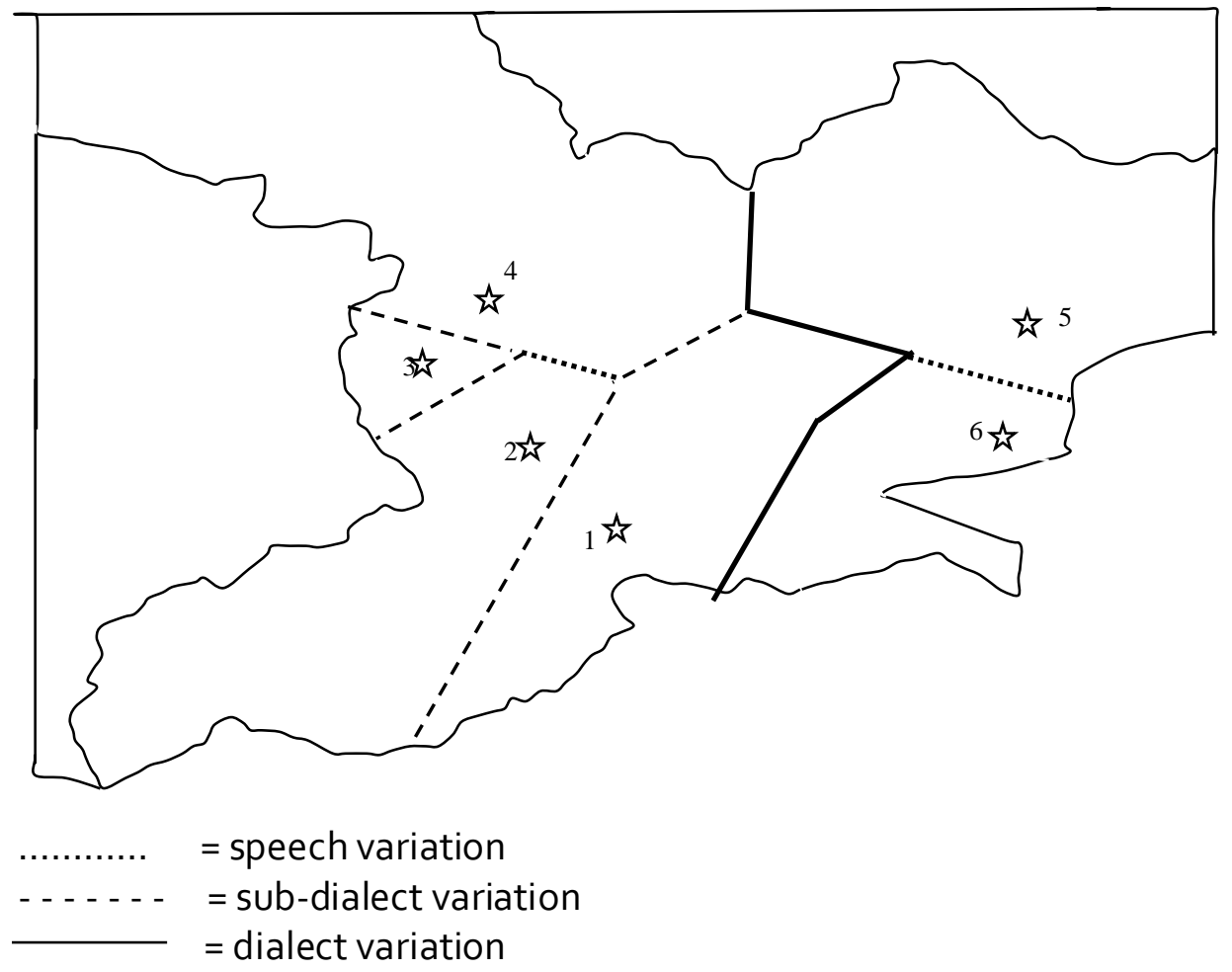

The writers used the PAN instrument from McFarland and Dyen (PANDYMC /1970) and also from Lopez (PANDLO) in the book of Wilson and Wurm (1978). Then, the PM instrument was used from Adelaar. The following data from PAN-OR at three regencies in Jambi Province were Innovation and relic.

Data gloss "Tiga (three)", PAN 616 *telu? found Innovation at OR areas. The data at area DP $1,2,3,4$ was reflected as [tiga]; DP 5 was reflected as [tige]; and DP 6 was reflected as [tigo]. The Innovation was occurring at DP 1,2,3,4 from *telu? > [tiga] indicated the change of *e > $i$ at the beginning of word at the first syllable; the change of $* \mid>g$; then the change of $* u>$ an in the second syllable and followed by the deletion of *? At the end of the second syllable was called 'haplology'. The Innovation was occurring at DP 5 from *telu? > [tige] indicated the change of ${ }^{*} \mathrm{e}>\mathrm{i}$ at the beginning of the first syllable; the change of $\mathrm{I}>\mathrm{g}$, then the change of $* u>e$ in the second syllable and followed by the deletion of *? At the end of the second syllable was 'haplology'. The Innovation was occurring at DP 6 from *telu? > [tigo] indicated the change of * $\mathrm{e}>\mathrm{i}$ at the beginning of the first syllable; the change of $\mathrm{I}>\mathrm{g}$; the change of $*_{U}>0$ at the second syllable and followed by the deletion of $*$ ?. It is called "haplology".

Data gloss "dua (two)"; PAN *DewS3a? discovered innovations in OR areas. The observation area DP 1,2,3,4 was reflected as [dua], DP 5 was reflected as [due]; and DP 6 was reflected as [duo]. The Innovation was occurring at DP 1,2,3,4 from *DewS3a? > [dua] indicated the change of $* D>d$; at the beginning of a word. The deletion of $*$ e occurring amid the word was also called 'syncope', followed by *w $>u_{i}$ the deletion of $* S_{3}$ sound was 
occurring amid the word called 'syncope', and followed by *? Occurring at the end of a syllable called 'haplology'.

Data gloss 'kaki' (foot), PAN *kaki[?h], and PM *kaki was a relic, then PM-OR also relic. The observation area DP 1,2,3,4,5,6 were reflected equally the same as [kaki]. The Innovation of PAN-PM in *kaki[?h] > *kaki no change, the meaning of *[?h] at the end of word PAN was optional. PM-OR was relic at DP 1,2,3,4,5,6 *kaki[?h] > *kaki also the same, there was no changing of words.

Data gloss 'hidung' (nose), PAN *qzijú and PM *hidun occurred Innovation, while PM-OR occurred relic at DP $1,2,3,4,5,6$ reflected as [hidひn]. The Innovation of PAN-PM *q2ijún > $*$ hid $\mho \eta$ indicated the change of ${ }^{*} q 2>* h$; and the change of $* j>* d$. PM-OR was relic

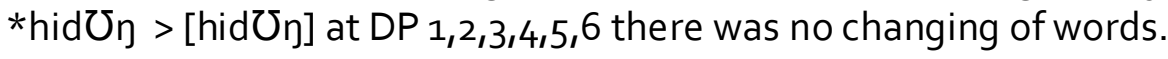

Data gloss 'gigi' (tooth), PAN * gigih, and PM *gigi occurred Innovation, while PM-OR was relic at all observation areas of DP $1,2,3,4,5,6$ reflected as gigi. The Innovation of PAN-PM *gigih $>$ *gigi leads to the deletion of *h at the end of the word called 'haplology'. Relic at PM-OR *gigi > [gigi] occurred no change.Data gloss 'payudara [breast]', PAN *susu? And $\mathrm{PM}$ *susu(?) belongs to a relic, then PM-OR also belongs to a relic. The observation area DP $1,2,3,4,5,6$ was reflected equally as [susu]. PAN-PM *susu? > *susu(?) showed no change. The meaning of the sign () was optional, may or may not be used. PM-OR was relic at DP $1,2,3,4,5,6$ *susu? > *susu (?), no change, the meaning *(?) at the end of word PM meant optionally. Based on all of the writers' data, here the result of PAN-PM-OR in the table below.

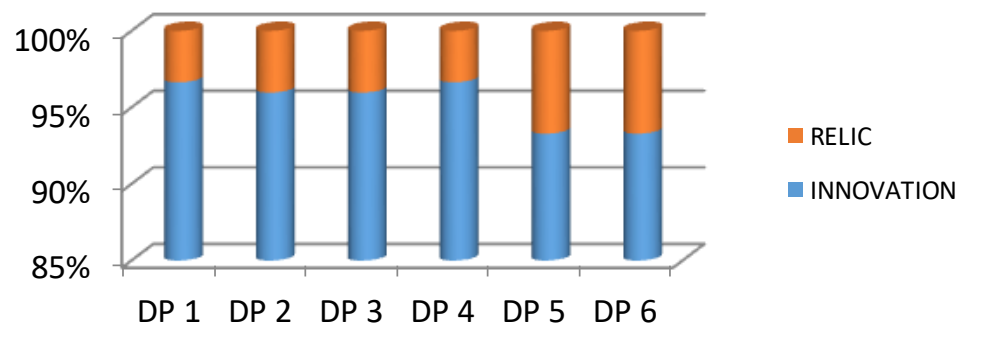

Figure 1. Innovation and Relic at PAN-OR in three Regencies of Jambi Province

From the graphic above, PAN-OR of Jambi province found 149 data. The data of Innovation was 148, and the relic was 14 data. So, the analysis of the data based on each group as follows:

1. T. Canggo at DP 6; 139 innovations and 10 relics.

2. T. Kubung at DP $5 ; 139$ innovations and 10 relics.

3. D. Begantung at DP $4 ; 144$ innovations and 5 relics.

4. T. Njalo at DP $3 ; 143$ innovations and 6 relics.

5. T. Berendam at DP 2; 143 innovations and 6 relics.

6. T. Betaring at DP $1 ; 144$ innovations and 5 relics. 


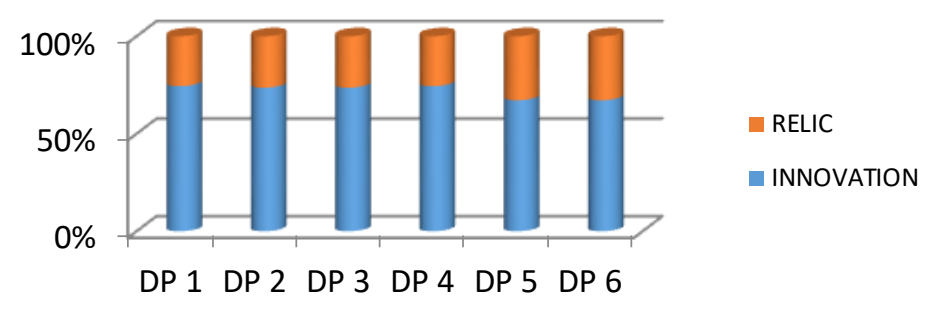

Figure 2. Innovation and Relic at PM-OR in three Regencies of Jambi Province.

This diagram reveals that the groups DP 5 and DP 6 were still maintaining PM vocabularies until today. The location of those groups was at Muaro Jambi regency. Meanwhile, the highest Innovation and lowest relic were DP 1 from Sarolangun and DP 4 from Tebo regencies, the finding was:

1. DP 6; T. Canggo-Muaro Jambi Regency; 86 innovations and 42 relics.

2. DP $5 ;$ T. Kubung-Muaro Jambi regency; 86 innovations and 42 relics.

3. DP $4 ;$ D. Begantung-Tebo regency; 93 innovations and 32 relics.

4. DP $3 ;$ T. Njalo-Tebo regency; 92 innovations and 33 relics.

5. DP $2 ;$ T. Berendam-Sarolangun Regency; 92 innovations and 33 relics.

6. DP $1 ;$ T. Betaring-Sarolangun Regency; 93 innovations and 32 relics.

Based on the data, most children entering elementary schools were in the Nebang Parah village, followed by Nyogan village. In comparison, the number of children attending school at the primary school level in the village of Pematang Kabau, Kedondong Mudo, and Tanah Garo has a small amount. Nebang Parah Village has an elementary school building in their village, as well as Nyogan village. OR in that village have high enthusiasm to encourage their children to go to school so that the number of children attending school increase every year. Another reason was that Nebang Parah and Nyogan village's position was just around 90 minutes from Jambi city, so the influence of important education was also high.

This condition was different from the OR community in Tebo and Sarolangun regencies. Pematang Kabau village, Kedondong Mudo, and Tanah Garo also had a school, or the school's position was not too far from the OR village. The problems that arise were, OR groups in these two regencies still maintain a tradition of Melangun. Melangun was the tradition of moving the old place to a new place if there is one of their family members died. Because of that, they were lazy to push their children to go to school. They learn only when there were NGO staff who comes to their groups; if the NGO staff does not come, the OR children in that area do not study.

This study's initial perception was that OR children in Muaro Jambi regency much go to school, meet new friends, new world, new environment, and language contact will occur. This group was vulnerable to language shifts. Children adapted themselves to the new environment, including the new vocabulary they hear. The new vocabulary must have been brought into the nuclear family, so there must have been a language shift in the OR group. This is different from the OR group from Tebo and Sarolangun districts. In this group, 
children rarely went to school, so their vocabulary was well maintained. They also rarely made language contact with outsiders, so that language shift is improbable.

This research showed that the high number of children attending school does not show a high language shift in the proto-language. This situation showed the strength of the nuclear family that maintains the Mother's language to their children. In other groups where the children little went to school show a language shift and a low percentage of proto-language maintenance.

\section{Conclusion}

Based on all of the data from lexical, phonological, the isolect of OR in Jambi province consisted of four dialects and two sub-dialects. Firstly, the area related to dialect variation was OR in Nebang parah, OR in Paku Aji, OR in Nyogan, and OR in Tanah Garo. Secondly, the area that included sub-dialect variation were $O R$ in Kedondong Mudo and $O R$ in Singosari. It happened because of: a) the areas had different characteristics of sound. The areas of $1,2,3,4$ were dominated by sound /0/, $/ 0 /$ while the areas 5,6 were dominated by sounds $/ \mathrm{e} / \mathrm{/} / \mathrm{a} / \mathrm{b}$ ) the distance between DP 1 and DP 5 , DP 6 or DP 4 and DP 5 were very far and impossible if they do communication. Based on that reason, it was reasonable if these groups belong to dialect variations; while area 2 and area 3 included dialect category, it indicated they had closed kinship relation. The community of DP 2 and DP 3 were still lived in the Bukit Duabelas forest. They also made communication contact with villagers, but it was not as often as made by other OR groups in DP 1 and DP $4 ; \mathrm{c}$ ) based on the residence area openness, areas 1 and 4 lived in palm plantation. Their position was not too far from the villager housing. DP 5 and DP 6, although living in the relocation area prepared by the Jambi government, the location far from the Malay village, and the areas 2 and area 3 were still inside the forest. Besides that, if each area was compared between the groups in the same regency, the result was sub-dialect except DP 5 and DP 6. It happened because of areas 5 and 6 included into the speech variation category. It means the kinship relation between areas 5 and 6 was very close. After that, the groups 1,2,3,4 referred to sub-dialect variation. It happened because those groups formerly often moved from one place to another place in the forest of Bukit Duabelas. They did intermarriage so that there were the same vocabularies appear in their conversation.

Proto Austronesian and Proto Malayic reflexes in Malayan sub-dialects of OR at Muaro Jambi, Sarolangun, and Tebo Regencies were: A) PAN-OR, firstly, the observation areas with the highest Innovation were DP 1 and DP 4: 144 data; DP with the highest relic was DP 5 and DP 6: 10 data. Secondly, DP with the lowest Innovation was DP 5 and DP 6: 139 data. Meanwhile, the lowest relicts were DP 1 and DP 4: 5 data. B) PM-OR; firstly, DP with the highest Innovation were DP 1 and DP 4: 93 data; then DP with the highest relic was DP 5 and DP 6: 86 data. Meanwhile, the lowest relic was DP 1 and DP 4: 32 data. C) PAN-PM-OR appeared Innovation and relic, they were: Innovation-Innovation was 61 data, Relic-Relic was 2 data, Innovation-Relic was 21 data, Relic-Innovation was 14 data, InnovationInnovation-Relic was 18 data, Relic-Innovation-Relic was 10 data. D) PAN-PM had 99 innovations and 26 relics. E) PAN-OR had 148 innovations and 14 relics. F) PM-OR had 102 innovations and 50 relics. G) PAN-PM-OR had 61 innovations and 2 relics.

The DP that still maintaining their proto-language from PAN or PM was DP 5 and DP 6 at Muaro Jambi Regency, and DP had many innovations from PAN or PM were DP 1 and DP 4. 
DP 1 came from Sarolangun Regency, and DP 6 came from Tebo Regency. Hight relics mean society still maintenance their father or mother language. Meanwhile, the lowest relics show that society used new words far from their parents' words. This finding is in line with education that the more children who attend to go to school, the better the protolanguage defense, the fewer children who attend to go to school, the greater protolanguage shift happen.

\section{References}

Adelaar, KA. (1992). Proto Malayic: The Reconstruction of Its Phonology and Parts of Its Lexicon and Morphology. Pacific Linguistics Series C-119. Australia: Department of Linguistic, Research School of Pasific Studies, The Australian National University.

Cahyono, Bambang Yudi. (1995). Kristal-Kristal Ilmu Bahasa. Surabaya: Airlangga University press.

Chaer, Abdul. (1994). Linguitik Umum. Jakarta: PT. Rineka Cipta.

Chambers and Trudgill. (1998). Dialectology. Second Edition. Great Britain: Cambridge University Press.

Chomsky, Noam. (2000). Cakrawala Baru Kajian Bahasa dan Pemikiran. (Alih Bahasa: Freddy Kirana). Jakarta: PT. logos Wacana Ilmu.

Crystal, David. (1992). An Introduction to Historical Linguistics. Cambridge: Cambridge University Press.

Dongen, G.J.Van. (1913a). Orang Kubu (Suku Kubu) di Daerah Kubu dari Residensi Palembang (Mimiograf). Translated by Hertini dan Budi prihatna.

Dongen, G.J.Van. (1913b). Masih Ada Informasi Lain Dalam Bahasa Kubu; dalam Birjdragen Tot De Taal-, Land-, En Volkenkunde Van Nederlandscb-Indie. (Mimiograf). Translated by Hertini dan Budi Prihatna.

Effendy, Hafid, M. (2011). Tinjauan Deskriptif Tentang Varian Bahasa Dialek Pamekasan. Vol. 1, Tahun 6, Mei 2011, Jurnal OKARA.

Fitria, Dewi dkk. (2017). Kajian Dialektologi Bahasa Madura Dialek Bangkalan. Vol. 4, No.2, Desember 2017, Jurnal Fonema.

Indriani and Ningrum. (2017). Kajian Kontrastif: Dialek Bahasa Jawa Pesisir dan Pegunungan di Kabupaten Pemalang. Vol.9, No.2, November 2017, Jurnal Bahasa Lingua Scientia.

Kridalaksana, Harimurti. (2001). Kamus Linguistik. Jakarta: PT. Gramedia.

Lass, Roger. (1991). Fonologi, Sebuah pengantar untuk Konsep-Konsep Dasar. Translated by Warsono, dkk. Semarang: IKIP Semarang Press.

Lee, Sharon E. (2013). Education as a Human Right in the 21 st Century. Democracy \& Education Journal, Vol 21, no1.

Ling, Jane Wong Kon. (2000). The Sabah Malay Dialect, Phonological Structures and Social Functions. Malaysia: UMS printing.

Mahsun. (1995). Dialektologi Diakronis, Sebuah Pengantar. Yogyakarta: Gadjah Mada University Press.

Mahsun. (2010). Genolinguistik, Kolaborasi Linguistik dengan Genetika dalam Pengelompokan Bahasa dan Populasi Penuturnya. Yogyakarta: Pustaka Pelajar. 
Mcmanis and Carolyn. (1987). Language Files, Materials for an Introduction to Language. Compilers of the Fourth Edition. America: The Ohio State University Department of Linguistics.

Nadra dan Reniwati. (2009). Dialektologi, Teori dan Metode. Yogyakarta: Elmatera Publishing.

Robins, R.H. (1975). General Linguistics, An Introductory Survey. London: Longman Group Limited.

Rozelin, Diana. (2014). Dialek Melayu Orang Rimba di Provinsi Jambi: Kajian Dialektologi. Disertasi Universitas Negeri Sebelas Maret (unpublish).

Rozelin, Diana and Azlan, Ulfatmi. (2019). Proto Malayic Reflection at Isolect of malay Jambi Seberang and Malay Sabak at Jambi Province. Proceeding of The 4 th International Seminar on Linguistics (ISOL-4). DOI https://doi.org/10.2478/9783110680027-007

Siregar, Nina. (2013). Persepsi Orang Tua Terhadap Pentingnya pendidikan Bagi Anak. Jurnal Ilmu Pemerintahan dan Sosial Politik, Vol.1, 2013: 11-27.

Subroto, Edi. (2011). Pengantar Studi Semantik dan Pragmatik. Surakarta: Cakrawala Media.

Trudgill, Peter. (1976). Sociolinguitics: An Introduction. United States of America: Penguin Books, Ltd.

Weinreich, Uriel. (1970). Languages in Contact Findings and Problems, 7th printing. Netherlands: Mouton \& Co.N.V.

Wurm, S.A. and Wilson. (1978). English Finderlist of Reconstructions in Austronesian Languages (Post Brandstetter). Australia: Department of Linguitics Research School of pacific Studies, The Australian National University.

\section{GLOSSARY}

D : Depati (The assistant of Vice Temenggung)

D : Dialect Variation

DP : Area Observation

OR : Orang Rimba

PAN : Proto Austronesian

PM : Proto Malayic

S : Sub-Dialect Variation

T : : Temenggung

W : Speech variation 